\section{Does Bank Size and Funding Risk Effect Banks' Stability? A Lesson from Pakistan}

Global Business Review 19(5) II66-II86 (C) 2018 IMI

SAGE Publications sagepub.in/home.nav DOI: I0.II77/09721509|8788745 http://journals.sagepub.com/home/gbr

@SAGE

\author{
Muhammad Ali ${ }^{1,2}$ \\ Chin-Hong Puah'
}

\begin{abstract}
The purpose of this research is to address the two important questions. Does bank size effect bank stability? Does funding risk explain bank stability? For this purpose, we have obtained a balanced panel data from the banking sector of Pakistan. The sample data consist over five Islamic and nineteen conventional banks from 2007 to 2015 . The results suggest that bank size has a negative effect on stability under Z-score model, while a positive relationship was found when stability is measured through risk-adjusted return on assets (RAROA) and risk-adjusted equity-to-asset ratio (RAEA). Moreover, funding risk has a positive relationship with bank stability under all three stability models. The results obtained from robustness check analysis confirm the strength of our findings, when inflation, financial development and GDP were used as controlled variables. Additionally, the impact of inflation and GDP on bank stability is negative, while a positive relationship is reported between bank stability and financial development under all three models. Overall, present research is a first attempt to empirically analyse the size-stability and funding risk-stability relationship in the banking sector of Pakistan.
\end{abstract}

\title{
Keywords
}

Stability, bank size, funding risk, financial institutions, Pakistan

\section{Introduction}

The financial institutions have always been concerned with limiting the bank size in order to ensure financial stability. But, after the recent financial crisis of 2007/2008, this issue has gained much more importance in recent days and requires more explanations (Adusei, 2015). The possible reason could be that empirical evidence accounted larger banks for the crisis, whereas these banks provide significant damage to several countries across the globe. Since the economies has emerged from the financial crisis,

\footnotetext{
' Department of Economics, Faculty of Economics and Business, Universiti Malaysia Sarawak, Kota Samarahan, Sarawak, Malaysia.

${ }^{2}$ Department of Business Administration, Iqra University, Karachi, Pakistan.
}

\section{Corresponding author:}

Muhammad Ali, Department of Economics, Faculty of Economics and Business, Universiti Malaysia Sarawak, 94300 Kota Samarahan, Sarawak, Malaysia.

E-mail: alisaleem_0I@yahoo.com 